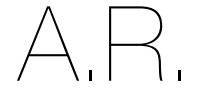

ARTIGO DE REVISÃO

1 EPIUnit - Instituto de Saúde Pública da Universidade do Porto,

Rua das Taipas, n. ${ }^{\circ} 135$ 4050-600 Porto, Portugal

2 Departamento de Ciências da Saúde Pública Forenses e Educação Médica da Faculdade de Medicina da Universidade do Porto,

Rua Doutor Plácido da

Costa,

4200-450, Porto, Portugal

${ }^{3}$ Faculdade de Ciências da Nutrição e Alimentação da Universidade do Porto, Rua Dr. Roberto Frias, 4200-465, Porto, Portugal

${ }^{4}$ i3S - Instituto de Investigação e Inovação em Saúde,

Rua Alfredo Allen,

4200-135, Porto, Portuga

*Endereço para correspondência anda Craveiro EPIUnit - Instituto de Saúde Pública da Universidade do Porto,

Rua das Taipas, n. ${ }^{\circ} 135$, 4050-600 Porto, Portuga

Histórico do artigo

Recebido a 7 de outubro de 2019 Aceite a 30 de dezembro de 2019

\title{
VITAMIN D - FROM THE PRO-HORMONE TO THE BIOLOGICAL ACTIONS
}

\author{
VITAMINA D - DA PRO-HORMONA ÀS AÇÕES BIOLÓGICAS
}

Vanda Craveiro"; ; Joana Araújo ${ }^{1,2}$; Alejandro Santos ${ }^{3,4}$; Elisabete Ramos ${ }^{1,2}$

\section{ABSTRACT}

Vitamin $\mathrm{D}$ (calciferol) is a fat-soluble pro-hormone presenting two major forms - vitamin $\mathrm{D}_{2}$ (ergocalciferol) and vitamin $\mathrm{D}_{3}$ (cholecalciferol). Vitamin $D_{2}$ is obtained via ultraviolet $B$ (UVB) irradiation of ergosterol, a fungi sterol, and vitamin $D_{3}$ is synthesized in the human/animal skin, after exposure of 7-dehydrocholesterol to UVB radiation. Both forms are produced commercially and found in supplements and in fortified foods. Either from the cutaneous synthesis $\left(D_{3}\right)$, or from the diet $\left(D_{2}\right.$ and $\left.D_{3}\right)$, both vitamins need to be activated, which requires two hydroxylation reactions, one mediated by the 25 -hydroxylase and other mediated by the 1a-hydroxylase. Thus, either vitamin $\mathrm{D}_{2}$ or $\mathrm{D}_{3}$ originate the calcitriol. This active metabolite is responsible for biological actions, characterized as genomic, mediated via the vitamin D receptor (VDR) transcriptional effects in the nuclei of target cells, and non-genomic, mediated via the rapid VDR-induced signal transduction pathways on the cell membrane and/or cytoplasm. Besides the endocrine actions of calcitriol (regulation of calcium and phosphorus, with interactions in the kidneys, bones, parathyroid glands, and small intestine), the ubiquitous presence of VDR in the organism contributes to the autocrine and paracrine actions of calcitriol, such as the inhibition of cell proliferation, promotion of cell differentiation (including differentiation of keratinocytes), apoptosis and immune regulation. Also, calcitriol is involved in the preventive and therapeutic action in cancer, auto-immune conditions (including type 1 diabetes), cardiovascular diseases, and infections.

\section{KEYWORDS}

Calcitriol, Vitamin D, Vitamin D receptor

RESUMO

A vitamina $\mathrm{D}$ (calciferol) é uma pró-hormona lipossolúvel que apresenta duas formas principais - vitamina $\mathrm{D}_{2}$ (ergocalciferol) e vitamina $D_{3}$ (colecalciferol). A vitamina $D_{2}$ é obtida via irradiação ultravioleta $B$ (UVB) do ergosterol, um esterol dos fungos, e a vitamina $D_{3}$ é sintetizada na pele humana/animal, após exposição do 7-desidrocolesterol à radiação UVB. Ambas as formas são produzidas comercialmente e encontradas em suplementos e alimentos fortificados. Quer provenham da síntese cutânea $\left(D_{3}\right)$, quer da dieta $\left(D_{2}\right.$ e $D_{3}$ ), ambas as vitaminas precisam de ser ativadas, o que requer duas reações de hidroxilação, uma mediada pela 25-hidroxilase e outra mediada pela 1a-hidroxilase. Assim, quer a vitamina $\mathrm{D}_{2}$ quer a $\mathrm{D}_{3}$ originam o calcitriol. Este metabolito ativo é responsáve por ações biológicas caracterizadas como genómicas, mediadas pelos efeitos transcricionais do recetor de vitamina D (VDR) nos núcleos das células-alvo, e não genómicas, mediadas pelas vias rápidas de transdução de sinal induzidas pelo VDR na membrana celular e/ou citoplasma. Além das ações endócrinas do calcitriol (regulação de cálcio e fósforo, com interações ao nível dos rins, ossos, glândulas paratiroides, e jejuno), a presença ubíqua de VDR no organismo contribui para as ações autócrinas e parácrinas do calcitriol, tal como a inibição da proliferação celular, promoção da diferenciação celular (incluindo a diferenciação de queratinócitos), apoptose e regulação da resposta imune. Além disso, o calcitriol está envolvido na ação preventiva e terapêutica do cancro, nas doenças autoimunes (como a diabetes tipo 1), doenças cardiovasculares e infeções.

PALAVRAS-CHAVE

Cacitriol, Vitamina D, Recetor da vitamina D

\section{Overview and Metabolism}

Vitamin $\mathrm{D}$, the fourth known vitamin - now recognized as a pro-hormone (1) -, was discovered in the early $20^{\text {th }}$ century $(2,3)$. At that time, there was a high prevalence of rickets with more than $90 \%$ of affected children in northern Europe (4). In 1921, the exposure to sunlight was reported as an effective treatment for rickets (5). In fact, the exposure to ultraviolet $\mathrm{B}$ radiation promotes the cutaneous synthesis of vitamin $D_{3}$, which is essential to the bone metabolism, regulating calcium and phosphorus levels in the organism (6). Thus, the rickets epidemic contributed to understand the association between sunlight and vitamin $\mathrm{D}$ for the promotion of bone health (7). Nowadays, it is well known that the effects of vitamin $D$ go beyond the skeletal health $(8,9)$.

\section{Introducing Vitamins $\mathrm{D}_{2}$ and $\mathrm{D}_{3}$}

Vitamin $\mathrm{D}$ (calciferol) encompasses fat-soluble seco-sterols 
and its two major forms are vitamin $D_{2}$ (ergocalciferol) and vitamin $D_{3}$ (cholecalciferol) $(1,10)$. Vitamin $D_{2}$ is obtained via ultraviolet $B$ (UVB) irradiation of ergosterol, a fungi sterol, found in plants and fungi (e.g., mushrooms, yeast), and vitamin $\mathrm{D}_{3}$ is synthesized in the human/animal skin, after exposure to UVB radiation, from 7-dehydrocholesterol (7$\mathrm{DHC})(1,8,10)$.

In humans, vitamin $D_{3}$ can be obtained directly from cutaneous synthesis or from diet.

The cutaneous synthesis of vitamin $D_{3}$ follows two steps (10). The first is the conversion of 7-DHC in pre-vitamin $\mathrm{D}_{3}$ by the exposure to the UVB radiation (290-315 nm) (10, 11); also, 7-DHC is converted to cholesterol by the enzyme 7-DHC reductase (12). The second is the spontaneous isomerization of pre-vitamin $\mathrm{D}_{3}$ in vitamin $\mathrm{D}_{3}$ by the exposure to body heat (thermo-sensitive but non-catalytic process) (10). The excessive exposure to UVB radiation degrades pre-vitamin $D_{3}$ and vitamin $D_{3}$ into inactive photoproducts $(4,8,11)$. Although the prolonged sun exposure helps to produce more amount of vitamin $\mathrm{D}_{3}$, it does not lead to toxic serum 25-hydroxyvitamin D [25(OH)D] (calcidiol) concentration (1).

Vitamin $D_{3}$ synthesized in skin enters the capillary system and it is transported by a plasma carrier protein - the vitamin D-binding protein (DBP) - to the liver for conversion (hydroxylation) or delivered to the storage tissues (adipose tissue, muscle, liver, etc) (13).

Vitamin $D_{2}$ (fungal and vegetal sources) or $D_{3}$ (animal sources) from diet are absorbed in the lumen of the small intestine, along with dietary fats. A part of the absorbed vitamin $D$ is transported into the portal system and reach directly the liver, and the other is incorporated into chylomicrons and reach the systemic circulation via the lymphatic system (1).

\section{Activation of Vitamin D}

Both vitamins $D_{2}$ and $D_{3}$ need to be activated, which requires two hydroxylation reactions, one mostly in the liver mediated by the 25-hydroxylase (25-OHase) and other, mostly in the kidney, mediated by the 1a-hydroxylase (1-OHase) $(1,10)$.

\section{From Vitamin D to 25(OH)D}

The first hydroxylation takes part mostly in the liver, but it also occurs in other tissues. During this process both vitamins $D_{2}$ and $D_{3}$ are converted to their respective 25 -hydroxymetabolites, by the $25-\mathrm{OHase}$, and are known collectively as total $25(\mathrm{OH}) \mathrm{D}$, which is the major circulating form of vitamin $D(4,8,11,14)$. This 25 -hydroxylation reaction is carried out by the two major cytochrome P450 mixed-function oxidases with 25-OHase activity: the CYP27A1 - the only mitochondrial 25-OHase; widely distributed in the body, not just in the liver - and the CYP2R1 - located in the endoplasmic reticulum; expressed primarily in the liver and testicles (10).

\section{From 25(OH)D to Calcitriol}

The second hydroxylation takes part mostly in the kidneys, but it also occurs in other tissues. 25(OH)D is biologically inactive and is converted, by the 1 -OHase, to 1,25-dihydroxyvitamin $\mathrm{D}[1,25(\mathrm{OH}) 2 \mathrm{D}]$ (calcitriol), the biologically active form of vitamin $D(1,8,10,15)$. This 1a-hydroxylation reaction is carried out by the only recognized CYP with 1-OHase activity: the CYP27B1 (10). Besides the kidneys, the CYP27B1, that is located in the mitochondria, is expressed in the epithelial cells, endocrine glands, immune system cells, osteoblasts and chondrocytes (10).

\section{Regulation of Calcitriol Concentration}

The renal 1-OHase is mainly regulated by three hormones: parathyroid hormone (PTH) (up-regulation), fibroblast growth factor 23 (FGF-23) (down-regulation), and calcitriol (down-regulation) $(10,16)$. Additionally, both calcium and phosphate play a role in the vitamin $\mathrm{D}$ endocrine system and besides having effect on renal CYP27B1 by their own, they also act as endocrine modulators - elevated calcium suppresses PTH, which inhibits CYP27B1 and elevated phosphate induces FGF-23, which inhibits CYP27B1 resulting in lower concentrations of calcitriol (10). Also, calcitriol directly inhibits CYP27B1 expression in the kidneys through a complex process involving vitamin $\mathrm{D}$ receptor (VDR, a steroid receptor) and a vitamin $\mathrm{D}$ inhibitory receptor (VDIR) (inhibition of the CYP27B1 transcription) (10). 25(OH)D and calcitriol are catalyzed by both 24-OHase (oxidation pathway) and 23-OHase (lactone pathway) (9, 10). The 24-OHase pathway results in the biologically inactive calcitroic acid (excreted through the bile), and the 23-OHase pathway results in the biologically active $1,25(\mathrm{OH}) 2 \mathrm{D}-26,23$ lactone $(8,10)$.

\section{Biological Actions of Vitamin D}

Calcitriol is responsible for the biological actions, characterized as genomic, mediated via the VDR transcriptional effects in the nuclei of target cells, and non-genomic, mediated via the rapid VDR-induced signal transduction pathways on the cell membrane and/or cytoplasm $(1,6,17,18)$.

In the genomic pathway, calcitriol enters the enterocyte and links to VDR, forming a complex, which constitutes a heterodimer with the retinoid $X$ receptor ( $R X R)$ (a nuclear receptor that is activated by retinoic acid), that binds to specific DNA sequences (vitamin D responsive elements [VDREs]) in target genes. VDREs are present in various human genes involved in endocrine and autocrine/paracrine functions, such as the inhibition of cell proliferation, promotion of cell differentiation (including differentiation of keratinocytes), apoptosis and immune regulation (1, $6,9,19)$. Thus, calcitriol has been hypothesized to contribute to the preventive and therapeutic action in cancer, auto-immune conditions (including type 1 diabetes), cardiovascular diseases, and infections (1, 8). In the non-genomic pathway, calcitriol binds to VDR localized in the caveolae of the plasma membrane and triggers signal transduction pathways that produce rapid responses, such as the rapid intestinal calcium absorption, secretion of insulin by pancreatic B-cells, regulation of chloride and calcium channels in osteoblasts, and the rapid migration of endothelial cells $(20,21)$.

Thus, since VDRs are ubiquitously dispersed throughout the organism, it contributes to the general role of calcitriol in the body tissues, which also includes the control of the 1) renin-angiotensin system, 2) insulin secretion, 3) muscle function, and 4) nervous system (6).

\section{Sources and Recommendations}

Vitamin $\mathrm{D}$ can be obtained through the endogenous cutaneous synthesis by the exposure to the UVB radiation, and by the intake of foods containing naturally present vitamin $D$ (e.g., fatty fish, egg yolk), foods fortified with vitamin D (e.g., milk, cereals), and medical supplements (e.g., cholecalciferol, calcifediol, calcitriol, alfacalcidol, paricalcitol) (1, 4).

\section{Cutaneous Synthesis}

During exposure to UVB radiation, 7-DHC (present in all the layers of human skin) is converted into pre-vitamin $\mathrm{D}_{3}(8,22)$. Holick suggested that more than $90 \%$ of the vitamin D requirement for most people is attained from casual exposure to sunlight (24). However, the report of the International Agency for Research on Cancer (IARC) on vitamin D and cancer did not support this statement and reinforced the importance of exogenous sources of vitamin $D(25)$.

Season and latitude are determinants of the cutaneous synthesis of vitamin $D_{3}(1)$. An increase in the maximum angle of the sun during winter and early morning and late afternoon results in a longer path 
for the solar UVB photons to travel through the ozone layer (5, 22). In a study conducted in Valencia (Spain), Serrano et al. observed that at latitudes above $40^{\circ} \mathrm{N}$ (i.e., the latitude of Porto, Portugal, is $41.2^{\circ} \mathrm{N}$ ) the sunlight was not strong enough to the endogenous synthesis of vitamin D, from November to February (26). They also found that in January, around noon, it takes more than two hours of solar exposure to obtain the recommended daily dose of vitamin $D$, whereas the rest of the year range between 7 minutes on July and 31 minutes on October (26). Webb et al. found similar results in Boston, USA $\left(42.2^{\circ} \mathrm{N}\right)$ but, in Edmonton, Canada $\left(52^{\circ} \mathrm{N}\right)$, the vitamin $\mathrm{D}$ winter period ranged between October and March (27). During these months the ultraviolet index $<3$ does not appear to be sufficient for the cutaneous production of vitamin $D(26,27)$. In Porto, Cabral et al. reported a peak of serum 25(OH)D concentration in August, and lowest 25(OH)D in February (28).

Additionally, the cutaneous production of vitamin $D_{3}$ is determined by individual, behavioral and environmental factors (1). Aging decreases the capacity of the skin to produce vitamin $D_{3}(29)$ and skin pigmentation is inversely related with this synthesis (1). Behaviors, such as, sunscreen use, clothing, or time of the day to outside activities also are determinants of skin exposure to sun and consequently of the availability to the endogenous cutaneous synthesis $(1,13)$.

In fact, although sunlight is an important contributor to the endogenous synthesis of vitamin $\mathrm{D}$, dietary intake may be particularly significant during winter in higher latitudes, for those people with minimal sun exposure or for those with individual characteristics less prone to the synthesis (30).

\section{Dietary Vitamin D}

The Institute of Medicine (IOM) determined the dietary reference intakes (DRIs) assuming a minimal sun exposure and established that 600 International Units (IU)/day(d) meet the needs of about $97.5 \%$ of the population with ages between 1 and 70 years old (1). This recommended dietary allowance (RDA) is equivalent to serum $25(\mathrm{OH})$ D concentration $\geq 50 \mathrm{nmol} / \mathrm{L}$ for maintaining bone health; the collected data did not provide compelling evidence for extra-skeletal health outcomes and for higher intakes being related with benefits for health (1). Moreover, the European Food Safety Agency (EFSA) recommends an adequate intake of $600 \mathrm{lU} / \mathrm{d}$ for all European population groups aged 1 year and more (13).

Dietary sources containing naturally present vitamin $\mathrm{D}$ include fatty fish (salmon, sardine, mackerel, tuna), offal (particularly liver), cod liver oil, meat and its products, and egg yolk $(8,13)$. Also, mushrooms and yeast are sources of vitamin $D_{2}$ (13). In fact, the presence of vitamin $D_{2}$ in vegetal sources is generally attributed to the presence of fungi but, interestingly, it was also found vitamin $\mathrm{D}_{3}$ in vegetables such as tomato and potatoes (31). Within the Portuguese Food Composition Table, fish and fish dishes constitute the items with $15 \mu \mathrm{g}$ and more of cholecalciferol per $100 \mathrm{~g}$ edible (Table 1) (32).

Despite the cutaneous synthesis and the natural presence of vitamin $\mathrm{D}$ in foods, a balanced and a diverse diet could not be sufficient to achieve the recommendations for this micronutrient (30). Thus, public health policies might be necessary to improve vitamin $D$ status at a population or community level, through the adoption of measures such as the promotion of dietary recommendations, food fortification, supplementation and cautious sun exposure, considering the country's cultural habits and UVB radiation index (30).

Food fortification strategies include mandatory or mass fortification of staple foods (e.g., milk, cereal flour) - mandated and regulated by the government when the bulk of the population is deficient in specific micronutrients -, targeted fortification - when adding sufficient amounts of micronutrients to provide large proportions

\section{Table 1}

Foods within the Portuguese Food Composition Table with $\geq 15 \mu \mathrm{g}$ of cholecalciferol per $100 \mathrm{~g}$ edible, adapted from Tabela da Composição dos Alimentos of Instituto Nacional de Saúde Doutor Ricardo Jorge (32)

\begin{tabular}{ll}
\multicolumn{1}{c}{$100 \mathrm{~g}$ OF EDIBLE FOOD } & $\mu$ O OF CHOLECALCIFEROL \\
\hline Raw conger & 91 \\
\hline Grilled sardine & 28 \\
\hline Fried sardine & 25 \\
\hline Sauteed stew conger with clams & 25 \\
\hline Grilled fattty sardine & 23 \\
\hline Grilled rainbow trout & 22 \\
\hline Conger & 21 \\
\hline Raw fatty sardine & 21 \\
\hline Fried fatty sardine & 20 \\
\hline Raw rainbow trout & 19 \\
\hline Grilled blackspot seabream & 17 \\
\hline Raw medium-fat sardine & 17 \\
\hline Fried medium-fat sardine & 16 \\
\hline Boiled whitemouth croaker & 16 \\
\hline Raw eel & 16 \\
\hline Raw whitemouth croaker & 16 \\
\hline Raw blackspot seabream & 15 \\
\hline Blackspot seabream in the oven & 15 \\
\hline Boiled blackspot seabream & 15 \\
\hline
\end{tabular}

of the daily needs through foods intended for specific population sub-groups (e.g., complementary foods for infants and foods for institutional programs) -, and market-driven or voluntary fortification - when manufacturers voluntarily add micronutrients (regulated by the government) to processed foods aiming to add value to their products, using fortification as a marketing instrument and thereby increasing sales (33).

The majority of the fortification with vitamin $D$ is made with the addition of vitamin $D_{3}$, but some milk alternatives are fortified with vitamin $D_{2}(34)$. Vitamin $\mathrm{D}$ fortification is mandatory in Canada - milk and margarine and is voluntary in the USA - milk and milk substitutes, ready-to-eat breakfast cereals, yogurts, cheeses, juices, and spreads are fortified with vitamin $D$ (34). In the UK margarines had mandatory fortification with vitamin D (and vitamin A) between 1940 and 2013 (30). Nonetheless, most margarines and fat spreads are still voluntarily fortified with vitamin D, as well as breakfast cereals and dried or evaporated milks (35). In Finland, milk and non-dairy alternatives such as soy and rice/oat drinks are fortified, and in Sweden and Iceland low-fat milks are fortified (30). The Netherlands and the DACH (Germany, Austria and Switzerland) countries do not have mandatory fortification for vitamin $D(30)$. All these countries have recommendations for vitamin $D$ supplementation targeting specific groups of the population (i.e., infants, children, pregnant women, elderly) (30).

Despite the fact of food fortification may be an important strategy to minimize the health consequences of very low serum $25(\mathrm{OH}) \mathrm{D}$ concentration in the population, it is important to highlight that the excessive oral intake of vitamin $\mathrm{D}$ can lead to hypervitaminosis $\mathrm{D}$, being the tolerable upper intake level (UL) defined as $4000 \mathrm{IU}(100 \mu \mathrm{g})$ for all population groups aged 9 years and more (1). The seasonal food fortification could be a way to prevent both the hypo and hypervitaminosis, helping to the maintenance of the vitamin D status during winter (36).

\section{Portuguese Situation}

In Portugal, some data concerning the vitamin D status is available. In particular, two population-based studies, presented data on the vitamin 
D status of adolescents/young adults $(37,38)$ and elderly $(39)$. In the Epidemiological Health Investigation of Teenagers in Porto (EPITeen cohort), it was reported a very low intake of vitamin D among 13 yearold teenagers, as well as a mean vitamin $D$ status consistent with risk of inadequacy (37). At 21 years of age, $48.9 \%$ of the individuals from the same cohort were at risk of inadequacy or deficiency of vitamin $D$ (38). Additionally, the Nutrition UP 65 reported more than two-thirds of elderly at risk of vitamin $D$ inadequacy or deficiency (39).

Portugal does not have a fortification policy for vitamin D (40) and there has been an abnormal increase of the use of vitamin D supplements, which was investigated by the Directorate-General of Health (41). The recommendation for universal vitamin $D$ supplementation exists in Portugal for infants during the first year, starting at the 2nd week of life (42). However, the Estudo do Padrão Alimentar e de Crescimento Infantil (EPACl study) reported that $31.7 \%$ of the infants were not taking vitamin D supplements (42). Elderly people ( $\geq 65$ years old) also have indication to take calcium and vitamin D supplements, as well as, younger women with higher risk of developing osteopenia (43).

The National Food, Nutrition and Physical Activity Survey of the Portuguese general population (IAN-AF) reported that more than onequarter of the population uses dietary/nutritional supplements, being this proportion higher among women and among adults and the elderly (44). The most ingested micronutrient in the elderly is calcium and in children is vitamin $D$, with a median of $4,9 \mu \mathrm{g} /$ day, which is far below the $15 \mu \mathrm{g} /$ day RDA for this group (44). In fact, IAN-AF found that the median intake of vitamin $D$ in each age group is less than the value indicated as appropriate for the respective group (44).

\section{CRITICAL ANALYSIS AND CONCLUSIONS}

In order to evaluate the vitamin D status, total serum $25(\mathrm{OH}) \mathrm{D}$ concentration is used as the biomarker of vitamin $D$ status, since it reflects the total vitamin $D$ exposure, from both diet and cutaneous synthesis $(1,13)$. It is important to note that vitamin $D$ and calcitriol have lower affinity for DBP than $25(\mathrm{OH}) \mathrm{D}$, and vitamin $\mathrm{D}$ has an average life-time in the body of approximately 2 months, 25(OH)D has 15 days and calcitriol has some hours (1). In the serum, $85-90 \%$ of $25(\mathrm{OH}) \mathrm{D}$ is transported bound to DBP, $10-15 \%$ is bound to albumin, and $<1 \%$ is free $(13,45)$.

The analytical method used to determine serum $25(\mathrm{OH}) \mathrm{D}$ concentration varies among studies, with the results being influenced by the type of assay and manufacturer, and there is no consensual method - i.e., competitive protein-binding assays, radioimmunoassay (RIA), high performance liquid chromatography (HPLC), liquid chromatographymass spectrometry (LC-MS), and the more recent automated immunoassays (46). Additionally, there is a lack of consensus on the range values of serum $25(\mathrm{OH}) \mathrm{D}$ concentration and on the cut-points for extra-skeletal health outcomes, which is critical considering both public health and clinical practice (1). The IOM suggests serum 25(OH) D concentration $>50 \mathrm{nmol} / \mathrm{L}$ as vitamin D sufficiency, $30-50 \mathrm{nmol} / \mathrm{L}$ as risk of vitamin $D$ inadequacy and $<30 \mathrm{nmol} / \mathrm{L}$ as risk of vitamin $D$ deficiency (1). Serum 25(OH)D concentration above $75 \mathrm{nmol} / \mathrm{L}$ are not consistently associated with increased benefit and there may be reason for concern at serum 25(OH)D concentration above $125 \mathrm{nmol} / \mathrm{L}$ (1). However, the Endocrine Society clinical practice guideline consider vitamin D sufficiency as $>30 \mathrm{ng} / \mathrm{mL}(75 \mathrm{nmol} / \mathrm{L})$ to maximize the effect of vitamin $\mathrm{D}$ on calcium, bone and muscle metabolism, insufficiency as $21-29 \mathrm{ng} / \mathrm{mL}$ (52.5-72.5 nmol/L), and deficiency as $<20 \mathrm{ng} / \mathrm{mL}$ (50 $\mathrm{nmol} / \mathrm{L})(47)$. Also, the Endocrine Society suggests that the tolerable upper intake level (UL) for patients at risk of vitamin D deficiency should be $10000 \mathrm{IU} / \mathrm{d}$ for all population groups aged 19 years and more (47).
Despite the differences in the analytical method and in the range values used when assessing vitamin D status, the worldwide vitamin D inadequacy/ deficiency is a current public health problem $(48,49)$. Strategies to improve this status should combine safe sun exposure, vitamin D naturally rich or fortified foods and, if needed, vitamin D supplements to attain serum $25(\mathrm{OH}) \mathrm{D}$ concentration $>50 \mathrm{nmol} / \mathrm{L}$ most of the year $(50)$.

\section{ACKNOWLEDGEMENTS}

This study was funded by FEDER through the Operational Programme Competitiveness and Internationalization and national funding from the Foundation for Science and Technology - FCT (Portuguese Ministry of Science, Technology and Higher Education) (POCl-01-0145FEDER-016829), under the Unidade de Investigação em Epidemiologia - Instituto de Saúde Pública da Universidade do Porto (EPIUnit) (POCl01-0145-FEDER-006862; Ref. UID/DTP/04750/2013; and the PhD Grant PD/BD/149264/2019 (Vanda Craveiro), co-funded by the FCT and the POPH/FSE Program.

\section{REFERENCES}

1. Institute of Medicine. Dietary reference intakes for calcium and vitamin D. Washington, DC: The National Academies Press; 2011.

2. Holick MF. McCollum award lecture, 1994: vitamin D - new horizons for the 21 st century. Am J Clin Nutr. 1994;60(4):619-30.

3. Wolf G. The discovery of vitamin D: the contribution of Adolf Windaus. J Nutr. 2004;134(6):1299-302.

4. Holick MF. The vitamin D deficiency pandemic: a forgotten hormone important for health. Public Health Rev. 2010;32(1):267-83.

5. Holick MF, Chen TC, Lu Z, Sauter E. Vitamin D and skin physiology: a D-lightful story. J Bone Miner Res. 2007;22 Suppl 2:V28-33.

6. Dusso AS, Brown AJ, Slatopolsky E. Vitamin D. Am J Physiol Renal Physiol. 2005;289(1):F8-28

7. Holick MF. Vitamin D status: measurement, interpretation, and clinical application. Ann Epidemiol. 2009;19(2):73-8.

8. Holick MF. Vitamin D deficiency. N Engl J Med. 2007;357(3):266-81.

9. Christakos S, Dhawan P, Verstuyf A, Verlinden L, Carmeliet G. Vitamin D: metabolism, molecular mechanism of action, and pleiotropic effects. Physiol Rev. 2016;96(1):365-408. 10. Bikle DD. Vitamin D metabolism, mechanism of action, and clinical applications. Chem Biol. 2014;21(3):319-29.

11. Holick MF. Biological effects of sunlight, ultraviolet radiation, visible light, infrared radiation and vitamin D for health. Anticancer Res. 2016;36(3):1345-56.

12. Prabhu AV, Luu W, Li D, Sharpe LJ, Brown AJ. DHCR7: a vital enzyme switch between cholesterol and vitamin D production. Prog Lipid Res. 2016;64:138-51.

13. EFSA NDA Panel. Scientific opinion on dietary reference values for vitamin D. EFSA Journal. 2016;14(10):4547-692.

14. Holick MF. The vitamin D deficiency pandemic and consequences for nonskeletal health: mechanisms of action. Mol Aspects Med. 2008;29(6):361-8.

15. Lips P. Vitamin D physiology. Prog Biophys Mol Biol. 2006;92(1):4-8.

16. Chanakul A, Zhang MY, Louw A, Armbrecht HJ, Miller WL, Portale AA, et al. FGF23 regulates CYP27B1 transcription in the kidney and in extra-renal tissues. PLoS One. 2013;8(9):e72816.

17. Haussler MR, Jurutka PW, Mizwicki M, Norman AW. Vitamin D receptor (VDR)mediated actions of 1a,25(OH)2 vitamin D3: genomic and non-genomic mechanisms. Best Pract Res Clin Endocrinol Metab. 2011;25(4):543-59.

18. Trochoutsou Al, Kloukina V, Samitas K, Xanthou G. Vitamin-D in the immune system: genomic and non-genomic actions. Mini Rev Med Chem. 2015;15(11):953-63. 19. Vanchinathan V, Lim HW. A dermatologist's perspective on vitamin D. Mayo Clin Proc. 2012;87(4):372-80.

20. Marquina C, Mousa A, Scragg R, de Courten B. Vitamin D and cardiometabolic disorders: a review of current evidence, genetic determinants and pathomechanisms. Obes Rev. 2019;20(2):262-77. 
21. Norman AW. Minireview: vitamin D receptor: new assignments for an already busy receptor. Endocrinology. 2006;147(12):5542-8.

22. Hossein-nezhad A, Holick MF. Vitamin D for health: a global perspective. Mayo Clin Proc. 2013;88(7):720-55

23. Alves M, Bastos M, Leitão F, Marques G, Ribeiro G, Carrilho F. Vitamina D importância da avaliação laboratorial. Rev Port Endocrinol Diabetes Metab. 2013;8(1):32-9.

24. Holick MF. Sunlight and vitamin D for bone health and prevention of autoimmune diseases, cancers, and cardiovascular disease. Am J Clin Nutr. 2004;80(6 Suppl):1678S-88S.

25. IARC. Vitamin D and Cancer. IARC Working Group Reports Vol.5. Lyon: International Agency for Research on Cancer, 2008

26. Serrano MA, Canada J, Moreno JC, Gurrea G. Solar ultraviolet doses and vitamin D in a northern mid-latitude. Sci Total Environ. 2017;574:744-50.

27. Webb AR, Kline L, Holick MF. Influence of season and latitude on the cutaneous synthesis of vitamin D3: exposure to winter sunlight in Boston and Edmonton will not promote vitamin D3 synthesis in human skin. J Clin Endocrinol Metab. 1988;67(2):373-8. 28. Cabral M, Araujo J, Lopes C, Barros H, Guimaraes JT, Severo M, et al. Relationship between dietary vitamin $\mathrm{D}$ and serum 25-hydroxyvitamin D levels in Portuguese adolescents. Public Health Nutr. 2018;21(2):325-32.

29. MacLaughlin J, Holick MF. Aging decreases the capacity of human skin to produce vitamin D3. J Clin Invest. 1985;76(4):1536-8.

30. Spiro A, Buttriss JL. Vitamin D: an overview of vitamin D status and intake in Europe. Nutr Bull. 2014;39(4):322-50.

31. Japelt RB, Jakobsen J. Vitamin D in plants: a review of occurrence, analysis, and biosynthesis. Front Plant Sci. 2013;4:136

32. Instituto Nacional de Saúde Dr. Ricardo Jorge. Tabela da Composição de Alimentos. Versão 2.0. Lisboa: Instituto Nacional de Saúde Dr. Ricardo Jorge, 2015.

33. Ritu G, Gupta A. Fortification of foods with vitamin D in India. Nutrients. 2014;6(9):3601-23.

34. Yetley EA. Assessing the vitamin D status of the US population. Am J Clin Nutr. 2008;88(2):558S-64S

35. Vitamin D and health. Scientific Advisory Committee on Nutrition. UK, 2016.

36. Gronborg IM, Tetens I, Christensen T, Andersen EW, Jakobsen J, Kiely M, et al. Vitamin D-fortified foods improve wintertime vitamin D status in women of Danish and Pakistani origin living in Denmark: a randomized controlled trial. Eur J Nutr. 2019.

37. Cabral M, Araujo J, Teixeira J, Barros H, Martins S, Guimaraes JT, et al. Vitamin $\mathrm{D}$ levels and cardiometabolic risk factors in Portuguese adolescents. Int J Cardiol. 2016;220:501-7.

38. Craveiro V, Cabral M, Araujo J, Falcao H, Guimaraes JT, Ramos E. Association of Serum 25-Hydroxyvitamin D Concentration with Pulmonary Function in Young Adults. Nutrients. 2018;10(11).

39. Santos A, Amaral TF, Guerra RS, Sousa AS, Alvares L, Moreira P, et al. Vitamin D status and associated factors among Portuguese older adults: results from the Nutrition UP 65 cross-sectional study. BMJ Open. 2017;7(6):e016123.

40. Vieira VL, Gregório MJ, Cervato-Mancuso AM, Graça APSR. Ações de alimentação e nutrição e sua interface com segurança alimentar e nutricional: uma comparação entre Brasil e Portugal. Saúde e Sociedade. 2013;22:603-7.

41. Infarmed, DGS e INSA avaliam diagnóstico e tratamento nacional com vitamina D. Lisboa: Infarmed, Direção-Geral da Saúde (DGS), Instituto Nacional de Saúde Dr. Ricardo Jorge (INSA), 2017.

42. Rêgo C, Nazareth M, Lopes C, Graça P, Pinto E. Suplementação vitamínica e mineral em Portugal durante o primeiro ano de vida. Resultados do EPACI Portugal 2012. Acta Pediatr Port. 2016;47:211-20.

43. Orientação técnica sobre suplemento de cálcio e vitamina $D$ em pessoas idosas. Lisboa: Direção-Geral da Saúde (DGS), 2008.

44. Lopes C, Torres D, Oliveira A, Severo M, Alarcão V, Guiomar S, Mota J, Teixeira P, Rodrigues S, Lobato L, Magalhães V, Correia D, Carvalho C, Pizarro A, Marques A, Vilela S, Oliveira L, Nicola P, Soares S, Ramos E. Inquérito Alimentar Nacional e de Atividade Física, IAN-AF 2015-2016: Relatório de resultados. Universidade do Porto,
2017. ISBN: 978-989-746-181-1.

45. Bikle DD, Gee E, Halloran B, Kowalski MA, Ryzen E, Haddad JG. Assessment of the free fraction of 25-hydroxyvitamin $D$ in serum and its regulation by albumin and the vitamin D-binding protein. J Clin Endocrinol Metab. 1986;63(4):954-9.

46. Wagner D, Hanwell HE, Vieth R. An evaluation of automated methods for measurement of serum 25-hydroxyvitamin D. Clin Biochem. 2009;42(15):1549-56.

47. Holick MF, Binkley NC, Bischoff-Ferrari HA, Gordon CM, Hanley DA, Heaney RP, et al. Evaluation, treatment, and prevention of vitamin D deficiency: an Endocrine Society clinical practice guideline. J Clin Endocrinol Metab. 2011;96(7):1911-30.

48. Hilger J, Friedel A, Herr R, Rausch T, Roos F, Wahl DA, et al. A systematic review of vitamin D status in populations worldwide. Br J Nutr. 2014;111(1):23-45.

49. Cashman KD, Dowling KG, Skrabakova Z, Gonzalez-Gross M, Valtuena J, De Henauw S, et al. Vitamin D deficiency in Europe: pandemic? Am J Clin Nutr. 2016;103(4):1033-44.

50. Bouillon R. Comparative analysis of nutritional guidelines for vitamin D. Nat Rev Endocrinol. 2017;13(8):466-79. 